http://jmscr.igmpublication.org/home/

ISSN (e)-2347-176x ISSN (p) 2455-0450

crossref DOI: https://dx.doi.org/10.18535/jmscr/v7i7.147

Journal Of Medical Science And Clinical Research

IGM Publication

An Official Publication of IGM Publication

\title{
Epidemiological Pattern of Dermatoses among Adults Attending Dermatology Outpatient Department in a Tertiary Centre in Central Kerala
}

\author{
Authors \\ Dr Preethi .K, Dr Deepa Augustine* \\ Department of Dermatology \& Venereology, Government Medical College \\ Kalamaserry, Ernakulam District, Kerala, India \\ *Corresponding Author \\ Dr Deepa Augustine
}

Assistant Professor, Department of Dermatology, Government Medical College, Ernakulam, Kerala, India

\begin{abstract}
Dermatoses vary from country to country and region to region. There are very few studies on epidemiological pattern of dermatosis. The pattern of dermatoses serve as an index of community development and quality of health care provision.A hospital based descriptive observational study was conducted in a tertiary centre, which is a teaching institution in the public sector in central Kerala, among adults who attended the dermatology outpatient department for a period of six months. The participants in the study were given a validated semi structured interview schedule in which sociodemographic variables such as age, sex, religion, educational qualification marital status, socioeconomic status, occupation and diagnosis on dermatoses were captured .The data collected was then entered and analysed.Non-infectious dermatoses were more compared to infectious dermatoses. Among infectious dermatoses fungal infections were the commonest and among non-infectious dermatoses eczemas were the commonest.More than half of the patients belonged to the 18 to 36 category. Females outnumbered males in the total op attendees. More than ninety percent of study population were literate and majority were students and unemployed .Less than three fourths of the participants were married and two thirds were above the poverty line. Majority of them were Muslims and resided in villages. However educational status and occupation did not have a significant influence on the pattern of dermatoses. Early diagnosis and management can prevent the spread of infectious dermatoses thereby reduce the burden of dermatoses in the society

Keywords: Epidemiology pattern, Dermatoses.
\end{abstract}

\section{Background}

Dermatoses are common in developing countries which can vary from less severe superficial fungal infections to life threatening drug reactions such as Steven Johnson syndrome and Toxic Epidermal necrolysis. The pattern of dermatoses serves as an index of community development and quality of care provision

\section{Introduction}

Dermatoses are very much prevalent in developing countries ${ }^{1}$ The prevalence of dermatoses in various studies varied from $6.16 \%$ to $51.9 \%$ in various studies ${ }^{2}$. In Denmark, Egypt and Singapore, non-infectious dermatoses are common, but in UK, premalignant and malignant dermatoses are more common ${ }^{4}$. In India infectious 
dermatosis are more common ${ }^{4}$. The pattern of dermatoses vary from country to country and from region to region, due to factors such as genetic, racial, regional, environmental, economic, socio cultural factors and level of literacy. ${ }^{1,2}$. Geographical factors like season and climate also contributes to the increased prevalence of certain type of skin dermatoses in a particular area. In developing countries low hygeine, poor access to water and overcrowding also play a role in case of certain diseases 3,4 . As dermatoses and their complications are a burden on the health system of a nation, epidemiological studies play a role ${ }^{1,8}$. Epidemiological studies play a role in determining disease pattern and for proper health care planning. ${ }^{16,18}$ But conducting epidemiological study is not an easy task, so hospital based studies are being conducted for convenience ${ }^{13}$.We do not have adequate data on incidence and prevalence of dermatological disorders in our country and we rely on the western data that is available.

During the last nine years no such epidemiological studies were conducted in Kerala .The present study was planned to get an insight into the various pattern of dermatoses in a tertiary care centre in Central Kerala and to study the relation between epidemiological factors and incidence of various dermatological disorders.

\section{Aims of the Study}

1. To study the epidemiological pattern of dermatoses among adults in the Dermatology outpatient department in a tertiary centre

\section{Materials and Methods}

A hospital based descriptive observational study conducted among all adults aged 18-60 years and speaking the regional language, who gave the informed written consent, attending the dermatology outpatient department in Government Medical College Ernakulam for a period of six months from February 2016 to July 2016 The participants in the study were given a validated semi structured interview schedule in which sociodemographic variables such as age, sex, religion, educational qualification ,marital status, socioeconomic status, occupation and diagnosis on dermatoses were captured .The data collected was then entered and analysed using SPSS version 21.Approval for the study was taken prior to data collection from Institutional Ethics Committee Government Medical College Ernakulam.

\section{Results and Interpretation}

Among the 4017 participants who were included in the study population the mean age was 36.10 . Taking age category into consideration ,more than half $(51.7 \%)$ of the participants belonged to the 18 to 36 years category and the rest $(48.3 \%)$ to the 37 to 60 age category.

Table 1 Age category

\begin{tabular}{|l|c|c|c|c|}
\hline Age group & Frequency & Percent & Valid Percent & Cumulative Percent \\
\hline $18-36$ & 2077 & 51.7 & 51.7 & 51.7 \\
\hline $36-60$ & 1940 & 48.3 & 48.3 & 100.0 \\
\hline Total & 4017 & 100.0 & 100.0 & \\
\hline
\end{tabular}

In the study populationless than two thirds $(63.6 \%)$ were females.

Table 2-Sex category

\begin{tabular}{|l|c|c|c|c|}
\hline Sex & Frequency & Percent & Valid Percent & $\begin{array}{c}\text { Cumulative } \\
\text { Percent }\end{array}$ \\
\hline Male & 1463 & 36.4 & 36.4 & 36.4 \\
\hline Female & 2554 & 63.6 & 63.6 & 100.0 \\
\hline Total & 4017 & 100.0 & 100.0 & \\
\hline
\end{tabular}

$98.2 \%$ of the study population were literate with $23.5 \%$ were graduates.

Table 3 Educational status

\begin{tabular}{|l|c|c|c|c|}
\hline Educational status & Frequency & Percent & $\begin{array}{c}\text { Valid } \\
\text { Percent }\end{array}$ & $\begin{array}{c}\text { Cumulative } \\
\text { Percent }\end{array}$ \\
\hline Illiterate & 73 & 1.8 & 1.8 & 1.8 \\
\hline Literate & 919 & 22.9 & 22.9 & 24.7 \\
\hline SSIC & 994 & 24.7 & 24.7 & 49.4 \\
\hline plus2 & 687 & 17.1 & 17.1 & 66.5 \\
\hline Technical & 217 & 5.4 & 5.4 & 71.9 \\
\hline Degree & 946 & 23.5 & 23.5 & 95.5 \\
\hline Professional/PG & 181 & 4.5 & 4.5 & 100.0 \\
\hline Total & 4017 & 100.0 & 100.0 & \\
\hline
\end{tabular}

Considering marital status, less than three fourths (72.7\%) were married and the rest belonged to the unmarried $(25.7 \%)$ separated $(0.3 \%)$ and widowed $(1.3 \%)$ category 
Table 4-Marital status

\begin{tabular}{|l|c|c|c|c|}
\hline Marital status & Frequency & Percent & Valid Percent & $\begin{array}{c}\text { Cumulative } \\
\text { Percent }\end{array}$ \\
\hline Unmarried & 1031 & 25.7 & 25.7 & 25.7 \\
\hline Married & 2920 & 72.7 & 72.7 & 98.4 \\
\hline $\begin{array}{l}\text { Separated/divorc } \\
\text { ed }\end{array}$ & 14 & .3 & .3 & 98.7 \\
\hline widow & 52 & 1.3 & 1.3 & 100.0 \\
\hline Total & 4017 & 100.0 & 100.0 & \\
\hline
\end{tabular}

More than half of the participants were unemployed and students (52.5\%).

Table 5 Occupational status

\begin{tabular}{|l|c|c|c|c|}
\hline occupation & Frequency & Percent & Valid Percent & $\begin{array}{c}\text { Cumulative } \\
\text { Percent }\end{array}$ \\
\hline government & 281 & 7.0 & 7.0 & 7.0 \\
\hline private & 818 & 20.4 & 20.4 & 27.4 \\
\hline business & 108 & 2.7 & 2.7 & 30.0 \\
\hline fisherman & 14 & .3 & .3 & 30.4 \\
\hline labourer & 260 & 6.5 & 6.5 & 36.9 \\
\hline sales & 48 & 1.2 & 1.2 & 38.1 \\
\hline driver & 162 & 4.0 & 4.0 & 42.1 \\
\hline painting & 37 & .9 & .9 & 43.0 \\
\hline mason & 65 & 1.6 & 1.6 & 44.6 \\
\hline tailor & 63 & 1.6 & 1.6 & 46.2 \\
\hline abroad & 23 & .6 & .6 & 46.8 \\
\hline farmer & 11 & .3 & .3 & 47.1 \\
\hline retired & 17 & .4 & .4 & 47.5 \\
\hline unemployed & 2110 & 52.5 & 52.5 & 100.0 \\
\hline Total & 4017 & 100.0 & 100.0 & \\
\hline
\end{tabular}

In the study population more than two third (67.4\%) belonged to the 'above poverty line' category and the remaining (32.6\%) to the 'below the poverty line'.

Table 6-socioeconomic status

\begin{tabular}{|c|c|c|c|c|}
\hline $\begin{array}{c}\text { socioeconomic } \\
\text { status }\end{array}$ & Frequency & Percent & $\begin{array}{c}\text { Valid } \\
\text { Percent }\end{array}$ & $\begin{array}{c}\text { Cumulative } \\
\text { Percent }\end{array}$ \\
\hline APL & 2709 & 67.4 & 67.4 & 67.4 \\
\hline BPL & 1308 & 32.6 & 32.6 & 100.0 \\
\hline Total & 4017 & 100.0 & 100.0 & \\
\hline
\end{tabular}

When religion was considered about less than half of the population were Muslims (43.1\%)

Table 7 Religion

\begin{tabular}{|c|c|c|c|c|}
\hline Religion & Frequency & Percent & Valid Percent & $\begin{array}{c}\text { Cumulative } \\
\text { Percent }\end{array}$ \\
\hline Hindu & 1595 & 39.7 & 39.7 & 39.7 \\
\hline & & & & \\
\hline Muslim & 1733 & 43.1 & 43.1 & 82.8 \\
\hline Christian & 688 & 17.1 & 17.1 & 100.0 \\
\hline others & 1 & .0 & .0 & 100.0 \\
\hline Total & 4017 & 100.0 & 100.0 & \\
\hline
\end{tabular}

More than half $(54.2 \%)$ of the participants resided in villages.

Table 8 Place of Residence

\begin{tabular}{|l|c|c|c|c|}
\hline Residence & Frequency & Percent & Valid Percent & $\begin{array}{c}\text { Cumulative } \\
\text { Percent }\end{array}$ \\
\hline city & 281 & 7.0 & 7.0 & 7.0 \\
\hline town & 1560 & 38.8 & 38.8 & 45.8 \\
\hline village & 2176 & 54.2 & 54.2 & 100.0 \\
\hline Total & 4017 & 100.0 & 100.0 & \\
\hline
\end{tabular}

Among dermatoses, non Infectious dermatoses constituted about $65.1 \%$ and infectious dermatoses (34.9\%).Fungal infections $(23.6 \%)$ constituted the majority in the infectious dermatoses category. Seasonal influence, environmental factors and misuse of topical steroids may be the reason for the higher percentage of fungal infections comparing previous studies ${ }^{11}$. Viral infections 3.4\%, bacterial infections, (6\%) parasitic infestations $(1.5 \%)$ and protozoal infections $(0.4 \%)$,Sexually transmitted infections $0.29 \%$, Hansens disease $(0.049 \%)$ respectively, STIs and Hansen's disease are less compared to previous studies which may be due to the proper implementation of National Health programmes. Among the non-infectious dermatoses eczemas $22.2 \%$ constituted the majority, vesiculobullous disorders $0.19 \%$, Hair disorders $1.49 \%$,mucosal disorders $0.22 \%$, Drug reactions $0.72 \%$, tumours $4.18 \%$,miliaria $6.52 \%$, lichen planus $0.9 \%$ autoimmune diseases like SLE $0.34 \%$

\section{Table .8 Dermatoses}

\begin{tabular}{|l|c|c|c|c|}
\hline Dermatoses & Frequency & Percent & Valid Percent & Cumulative Percent \\
\hline Noninfectious & 2614 & 65.1 & 65.1 & 65.1 \\
\hline Bacterial & 243 & 6.0 & 6.0 & 71.1 \\
\hline Viral & 136 & 3.4 & 3.4 & 74.5 \\
\hline Fungal & 948 & 23.6 & 23.6 & 98.1 \\
\hline Parasitic & 59 & 1.5 & 1.5 & 99.6 \\
\hline Protozoal & 17 & .4 & .4 & 100.0 \\
\hline Total & 4017 & 100.0 & 100.0 & \\
\hline
\end{tabular}

Pie chart

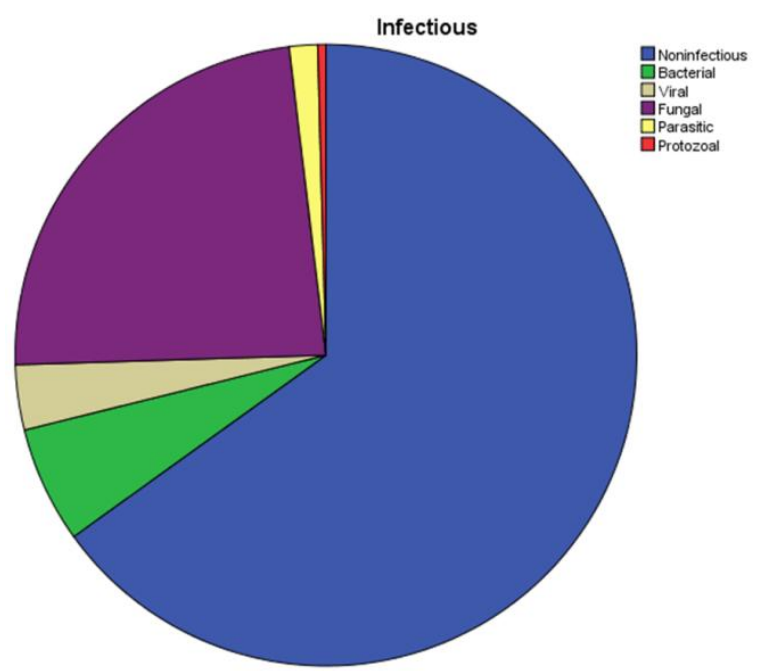


Table .9 Non-infectious

\begin{tabular}{|l|c|c|}
\hline Noninfectious & Frequency & Percent \\
\hline $\begin{array}{l}\text { Psoriasis\& disorders of } \\
\text { keratinisation }\end{array}$ & 90 & $2.2 \%$ \\
\hline Hair & 89 & $2.2 \%$ \\
\hline Nail & 5 & $.1 \%$ \\
\hline Eczema & 922 & $22.2 \%$ \\
\hline Vesiculobullous & 8 & $.2 \%$ \\
\hline Autoimmune & 38 & $2.77 \%$ \\
\hline Congenital & 9 & $.2 \%$ \\
\hline Traumatic & 3 & $.1 \%$ \\
\hline Pruritus & 177 & $4.4 \%$ \\
\hline Mucosal disorders & 9 & $0.22 \%$ \\
\hline Miliaria & 262 & $6.5 \%$ \\
\hline tumours & 168 & $4.18 \%$ \\
\hline Lichen planus & 39 & $0.9 \%$ \\
\hline Drug reaction & 29 & $0.72 \%$ \\
\hline Hair disorders & 60 & $1.49 \%$ \\
\hline
\end{tabular}

\section{Discussion}

When considering the disease pattern, $65.1 \%$ were non-infectious which is out of tune with the findings by researchers in southern India where infections were common. But studies in Guwahati and Uttarakhand showed a similar picture. In the non-infectious group, Eczemas constituted the majority $(22.2 \%)$. In this study healthy age group of 18-60 was considered and more than 50\% were of the younger age group ${ }^{(18-36)}$. This was at par with similar studies conducted in Telangana and Wardha $^{20}$.The reason for this increase could be the social mobility of the younger population .In this study females were the majority which is similar to other studies ${ }^{1,2,4,6}$. The better socioeconomic positioning as evidenced by $67.4 \%$ could be the reason for the reduction in the infection load. Among the infective conditions, fungal infections accounted for $23.6 \%$, which is the case in most studies in India, Bangladesh and a study from Pakistan, which could be due to the warm and humid climatic conditions. The religious practices and the traditional attire would be the reason contributing to the increased incidence of fungal infections in Muslims in this study.'

In this study, the patients attending the outpatient department were mostly literate, $24.7 \%$ with secondary education and $23.5 \%$ being degree holders. Increased literacy rate, leading to health consciousness and increased awareness may be the reason for the increased number of female patients $(63.6 \%)$ compared to other studies were it was $50 \%{ }^{2,4,6,8,9} .50 \%$ of the study population resided in villages and outpatient attendance is $16.33 \%$, which is more, when compared to studies conducted in Trivandrum in 1976 by Gangadharan $\mathrm{C}$ et al and in Thrissur, nine years back by Ashokan et al. This is also more when compared to $6.16 \%$ and $6.3 \%$ seen in studies conducted in Uttarakand and Gawahati respectively. The educational status and occupation did not have a significant effect on the pattern of dermatoses which is similar to other studies. ${ }^{2}$ Unemployed category was found to be more than $50 \%$. This could be because the students were not separately categorised in our study. ${ }^{1}$ Early identification of dermatoses is important for treating patients and also to prevent the spread of infectious dermatoses.

\section{References}

1. Aman S, Nadeem M, Mahmood K, Ghafoor MB. Pattern of skin diseases among patients attending a tertiary care hospital in Lahore, Pakistan. J TaibahUniv Med Sc 2017;12(5):392e396.

2. Bommakanti, Janardhan; Pendyala, Pradeep. Pattern of skin diseases in rural population: a cross sectional study at Medchal mandal, Rangareddy district, Telangana, India. International Journal of Research in Medical Sciences, [S.1.], v. 5, n. 1, p. 50-55, dec. 2016. ISSN 2320-6012

3. Sarkar SK, Islam AKMS, Sen KG, Ahmed ARS. Pattern of skin diseases in patients attending OPD of dermatology Department at Faridpur Medical College Hospital, Bangladesh. Faridpur Med Coll J. 2010;5(1):14-6.

4. Alahi, M. N., Hossain, M. A., \& Mohammad, A. (2018). Pattern of Skin Diseases in Patients Attending OPD of Dermatology and Venereology in a Tertiary Care Hospital in Bangladesh. Journal of National Institute of 
Neurosciences Bangladesh, 4(2), 116-122. https://doi.org/10.3329/jninb.v4i2.38926

5. Asokan N, Prathap P, Ajithkumar K, Ambooken B, Binesh VG, George S. Pattern of skin diseases among patients attending a tertiary care teaching hospital in Kerala. Indian J Dermatol Venereol leprol. 2009;75:517

6. Baghestani S, Zare S, Mahboobi AA. Skin disease patterns in Hormozgan. Iran Int $\mathbf{J}$ Dermatol. 2005;44:641-5.

7. Das S, Chatterjee T. Pattern of skin diseases in a peripheral hospital's skin OPD: A study of 2550 patients. Ind J Dermatol. 2007;52:93-5.

8. Vishal Prakash Giri, Om Prakash Giri, Sudhir Kumar Gupta, Shubhra Kanodia.Vishal et al., Clinicoepidemiological profile of inflammatory and infective skin diseases in a tertiary care centre in East India. Int $\mathbf{J}$ Med Res Health Sci. 2014;3(4):892-896

9. Gangadharan C, Joseph A, Sarojini PA. Pattern of skin diseases in Kerala. Indian J Dermatol Venereol leprol. 1976;42:49-51.

10. Kuruvilla M, Sridhar K S, Kumar P, Rao G. Pattern of skin diseases in Bantwal Taluq, Dakshina Kannada. Indian J Dermatol Venereol Leprol 2000;66:247-8

11. N.S Jayanthi et al. Epidemiological Pattern of Skin Diseases Among Patients Attending Dermatological Outpatient Department at a Tertiary Care Centre, North Chennai Indian Journal of Clinical and Experimental Dermatology, OctoberDecember 2017;3(4):134-137

12. Das KK. Pattern of dermatological diseases in Gauhati medical college and hospital Guahati. Indian J Dermatol Venereol Leprol. 2003;69:16-8

13. Devi T, Zamzachin G. Pattern of skin diseases in Imphal. Indian $\mathbf{J}$ Dermatol 2006;51:149-50.
14. Jaiswal A K. Ecologic perspective of dermatologic problems in North Eastern India. Indian J Dermatol Venereol Leprol 2002;68:206-7

15. Agarwal S, Sharma P, Gupta S, Ojha A. Pattern of skin diseases in Kumaun region of Uttarakhand. Indian $\mathrm{J}$ Dermatol Venereol Leprol. 2011 Sep-Oct;77(5):6034.

16. Alhoqail, Ibrahim. (2013). Epidemiological spectrum of common dermatological conditions of patients attending dermatological consultations in Al-Majmaah Region (Kingdom of Saudi Arabia). Journal of Taibah University Medical Sciences. 8. 31-37. 10.1016/j.jtumed.2013.01.011.

17. Das DA, Haldar HS, Das DJ, Mazumdar MG, Biswas BS, Sarkar SJ. Dermatological disease pattern in an urban institution in Kolkata. Ind $\mathbf{J}$ Dermatol. 2005;50:22-3.

18. Nnoruka EN. Skin diseases in south-east Nigeria: A current perspective. Int $\mathrm{J}$ Dermatol. 2005;44:29-33.

19. Alakloby OM. Pattern of skin diseases in Eastern Saudi Arabia. Saudi Med J. 2005;26:1607-10.

20. Grover S, Ranyal RK, Bedi MK. A cross section of skin diseases in rural Allahabad. Indian J Dermatol 2008;53:179-81. 